-

\title{
Blockchain-based Decentralized Distribution Management in E-Journals
}

\author{
Farida Agustin ${ }^{1}$, Syafnidawati ${ }^{2}$, Nuke Puji Lestari Santoso ${ }^{3}{ }^{3}$, Oktika Gita
}

\section{Amrikhasanah}

STIE AI-Khairiyah ${ }^{1}$, Raharja University 2,3,4

Jl. Jenderal Sudirman No.40, RT.002 / RW.006, Cikokol, Kec. Tangerang, Tangerang City, Banten 15117

e-mail: faridaagustin@stie-alkhairiyah.ac.id, syafnidawati@raharia.info, nuke@raharia.info, oktika@raharja.info

To cite this document:

Agustin, F., Syafnidawati, S., Lestari Santoso, N. P., \& Amrikhasanah, O. (2020). Blockchain-based Decentralized Distribution Management in E-Journals. Aptisi Transactions on Management (ATM), $4(2), 107-113$.

DOI:

https://doi.org/10.33050/atm.v4i2.1294

\begin{abstract}
The application of blockchain in the context of E-Journal distribution to journalists is aimed at making the management paper adequately distributed and not misused. The security system in the distribution or management paper process of an open journal system is currently considered to be very lacking because one can duplicate the journal in an open journal system easily. Furthermore, it can be transferred to anyone who is not responsible. The security system in the distribution of an open journal system and the management of the management paper process is currently considered to be very lacking because one can duplicate the journal in an open journal system easily. Furthermore, it can be transferred to anyone who is not responsible. With the implementation of this blockchain technology, there are 3 (three) benefits, namely (1) The distribution of E-Journal in the Open Journal System is more targeted, and there are no errors. (2) The reputation of the Open Journal System becomes better with a sense of trust. This research will be implemented in an E-Journal in an Open Journal System using blockchain technology. (3) The management paper processing in the open journal system runs according to the procedure so that in the management process the distribution of soft copies and hard copies of the journal is protected from hacker threats, and this blockchain is used to guarantee its security.
\end{abstract}

Keywords: Management, Blockchain, Distribution, E-Journal

\section{Introduction}

As we now know, Indonesia has entered the era of revolution 4.0, which caused changes in all fields [1]. Presentation of information must be more up-to-date and have a breakthrough in sophisticated information technology [2]. Nowadays getting information is not a difficult thing that relies on ancient tools, but the existence of a computer is a tool that makes it very easy to develop 
systems that are still considered not up to date [3]. At this time, the journal publishing system and management paper process have also been done online, which can be accessed by anyone and anywhere called E-Journal [4] [5] [6]. So that many people can pour their scientific work in the hope that their scientific work can be published and become teaching material for others who are trying to do scientific work as well.

Furthermore, people can quickly get a journal at the journal publisher's place by downloading or other means, so obviously the security of the scientific work that we publish is questionable about its safety. Retrieve data easily, duplicate it, change data. So the application of blockchain technology as a system to maintain security in the distribution of electronic journals and paper management processes [7] [8]. Distribution in the form of softcopy and hardcopy, an e-journal is one thing that makes sense, so security must be guaranteed as well [9] [10]. Furthermore, in the management paper process also requires security in every process, it is essential to have blockchain technology as a supporter of security in the management paper itself.

\section{Research Method}

In this study, using the waterfall method by having 7 (seven) sequential stages and if needed, several parts have feedback loops [11] [12]. And the following stages in the Waterfall Method [13]:

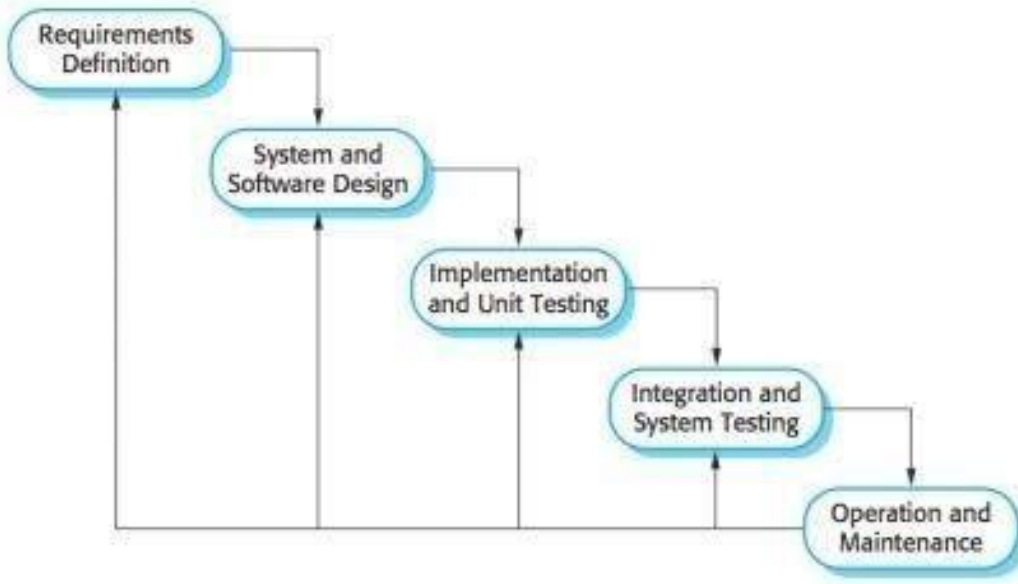

Figure 1. Sommerville Version Waterfall Method

1. Analysis of requirements and definitions

Analyzing the problems that exist in the distribution process of E-Journal and the process of circulation management paper to make it easier for users and E-security Journal can be maintained [14].

2. System design and design software

The e-journal embedded by the blockchain uses an encryption code to download documents that are only given access by the admin, so the management paper runs according to the flow. This design involves identifying and describing the basic system abstractions of software and their relationships [15].

3. Unit implementation and testing

At this stage, the blockchain design is realized by a series of programs and testing is also carried out in the form of verification that the system meets its specifications before entering the management paper process [16].

4. System integration and testing 
Unit programs or shared programs are tested as complete systems to ensure that they meet the user's needs in downloading E-Journal files or not. After testing, the system can

be implemented and used by the user or admin in downloading the E-Journal or the management paper process [17].

5. Operation and maintenance

Care has taken in its application and all forms of development of this blockchain technology in the E-Journal to enhance the new system's service requirements to support the security of the E-Journal or the management paper process [18].

\section{Results and Analysis}

Distribution systems are integrated monopoly systems and are generally given protection in each of these processes [19]. At present, the distribution in this E-Journal is very reasonable [20]. Because of the need to thirst for knowledge in this modern era, so as not to miss and be able to create the latest technological innovations. A change is needed in various fields such as the form of information presentation, so that information can be useful and quickly understood [21]. However, in the development of these developments there are positive and negative sides of a technology, so this change is called the disruptive era [22].

Furthermore, the problems that have been explained earlier distribution in this journal are positive things, but the basic negative things that follow [23]. Blockchain technology has evolved and not only deals with finance but has been applied in everyday life [24] [25]. The emerging blockchain has many useful features, such as freedom of trust, transparency, pseudonym, democracy, automation, decentralization, and security [26]. The concept of the blockchain itself is that the sealing of the block helps in making the blockchain by the security requirements of the E-Journal distribution or the paper management process is running [27].

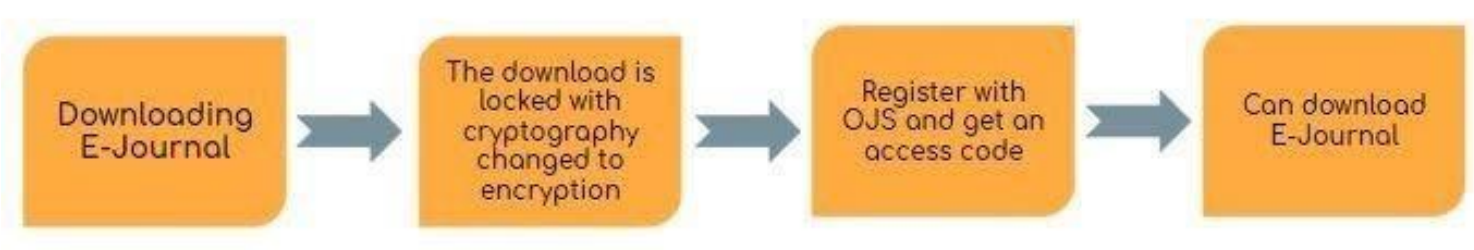

Figure 2. Blockchain-based workflow

1. Downloading E-Journal: If someone wants to see, save and distribute E-Journal, it cannot be downloaded easily and in the process of management paper flow also involves people who have been given access [28] [29] .

2. The download is locked with cryptography converted to encryption: If someone wants to download a file or violate the procedures in management paper then the user must be given an encryption code to send to who will be given access [30] [31].

3. Register with OJS and get an access code: After registering, the downloader gets an access code to enter OJS, so you can download the journal and process the desired management paper flow [32] [33].

4. Can download E-Journal: After getting access, customers can download journals and carry out management paper processing activities as desired [34] [35]. 


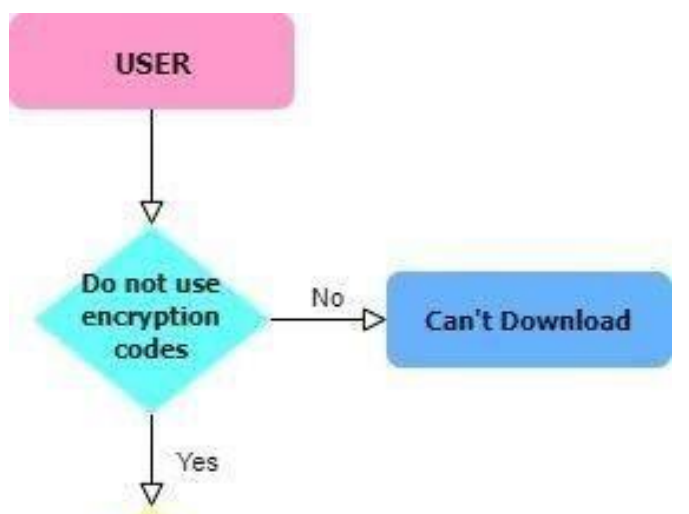

Request Accses

$\left.\right|_{\nabla}$ Yes

Get an encryption codes<smiles>[Te][Te]</smiles>

Download E-

Journal

Figure 3. Flowchart Blockchain E-Journal

From Figure 3 (three) above, it can be seen that the section depicted with a Flowchart diagram can be accessed by users and administrators who are in charge of processing paper management. Users can access or download E-Journal files after accessing the admin and getting the encryption code.
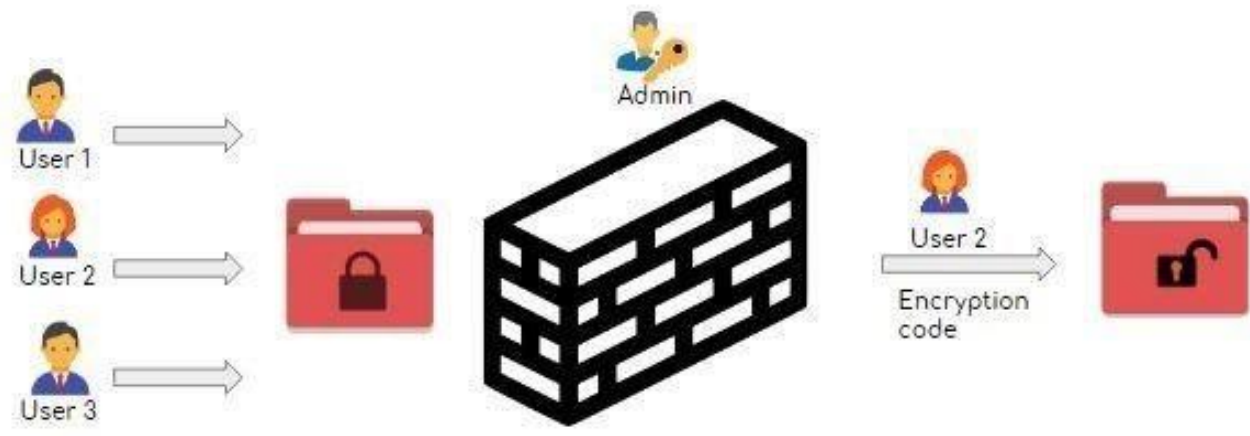

Figure 4. The Encryption Code Process

Figure 4 (four) above, it can be seen how the encryption code can fortify users who do not have E-Journal access and misuse the flow of management paper that is not by procedures. So E-Journal files can be protected and cannot be duplicated.

\section{Conclusion}

The research that authors can take is described in 3 (three) conclusions as follows: 
1. E-journal management with decentralized Blockchain technology can protect the manager's workflow online.

2. Blockchain technology can be implemented in an open journal system that is useful for preventing hackers who can download and change the paper management process without permission.

3. Management with a decentralized Blockchain can be a safe distribution tool, thereby increasing the reputation of the open journal system and simplifying management paper processing flow.

\section{References}

[1] Rahardja, U., Aini, Q., Graha, YI, \& Khoirunisa, A. (2019, May). Implementation of Gamification in Educational Management to Motivate Students. In the Proceeding Interuniversity Forum to Strengthen Academic Competence (Vol. 1, No. 1, pp. 209-209).

[2] Rahardja, U., Aini, Q., Hayat, A., \& Santoso, NPL APPLICATION OF GAMIFICATION ON ABSENTION ASSESSMENT TO INCREASE THE GUIDANCE MOTIVATION. EDUTECH, $18(1), 12-24$.

[3] Rahardja, U., Hidayanto, AN, Hariguna, T., \& Aini, Q. (2019, November). Design Framework on Tertiary Education Systems in Indonesia Using Blockchain Technology. In 2019 7th International Conference on Cyber and IT Service Management (CITSM) (Vol. 7, pp. 1-4). IEEE.

[4] ANWAR, MS (2019). E-JOURNAL SEARCH SYSTEM USING REMOVAL STOPWORD AND STEMMING BASED ON ANDROID (Doctoral dissertation, Sultan Agung Islamic University).

[5] Famous, F. (2016). e-Journal of Communication and Information Research and Development The Science today is the technology of tomorrow BOARD OF RESEARCH AND DEVELOPMENT OF THE MINISTRY OF COMMUNICATION AND INFORMATICS.

[6] Muhayat, M. (2019). DESIGN AND IMPLEMENTATION OF E-JOURNAL FACULTY OF DAKWAH AND COMMUNICATION USING THE OPEN JOURNAL SYSTEM APPLICATION. PAHLAWAN, 9 (02), 62.

[7] Rahardja, U., Handayani, I., \& Wijaya, R. (2018). The implementation of Technomedia Journal Viewboard uses the iLearning Journal Center system in Higher Education. Journal of Technomedia, 2 (2), 81-93.

[8] Rahmadika, S., Ramdania, DR, \& Harika, M. (2018). Security Analysis on a Decentralized Energy Trading System Using Blockchain Technology. Online Journal of Informatics, 3 (1), 44-47.

[9] FAUZI, MRR (2017). IMPLEMENTATION AND ANALYSIS OF USE OF HOW TO TRANSACTION WORK IN BITCOIN BLOCKCHAIN.

[10] Butar, MB (2019). DESIGN OF FERTILIZER DISTRIBUTION DATA PROCESSING INFORMATION SYSTEM USING E-SUPPLY CHAIN MANAGEMENT METHOD (CASE STUDY: PT. GUDANG PENYANGGA DAIRI). Information and Scientific Technology

(INTI), 14 (1), 29-32. 
[11] Warsito, AB, Yusup, M., \& Makaram, I. (2015). Designing SIS + Using the YII Framework Method at Raharja College. CCIT Journal, 8 (2), 24-33.

[12] Edison, M., Firdaus, MFG, \& Atmojo, WT (2020). Making Anime Wallpaper Applications Using the Waterfall Method in Pt. N3konime. Journal of Informatics Innovation, 5 (1), 83-90

[13] Nugroho, Y. (2020). N, Yogi Designs an Augmented Reality-Based Electronic Marketing Application Using the Waterfall Method. Journal of Computer Development, 2 (1), 66-73.

[14] Suryadi, A., \& Zulaikhah, YS (2019). Design and Build a Web-Based Archive Management System Using the Waterfall Method. Journal of the Equator Informatics, 7 (1).

[15] Alda, M. (2020). LAUNDRY INFORMATION SYSTEM USING ANDROID BASED WATERFALL METHOD IN LAUNDRY FRESH SIMPLY. JurTI (Journal of Information Technology), 3 (2), 122-129.

[16] Sasmito, GW (2017). Waterfall Application Method on Industrial Geographic Information System Design in Tegal Regency. Journal of Informatics: Journal of IT Development, 2 (1), 6-12.

[17] Hidayat, R., Marlina, S., \& Utami, LD (2017). Design of Website-Based Information System for Handmade Goods Sales Using the Waterfall Method. Simnasiptek 2017, 1 (1), 175-183.

[18] Larasati, H., \& Masripah, S. (2017). Analysis and Design of Grc Purchasing Information System Using the Waterfall Method. Pilar Nusa Mandiri Journal, 13 (2), 193-198.

[19] Umeh, J. (2016). Blockchain double bubble or double trouble? Itnow, 58 (1), 58-61.

[20] Harahap, EP, Aini, Q., \& Anam, RK (2020). USE OF BLOCKCHAIN TECHNOLOGY IN CROWDFUNDING PLATFORM. Technomedia Journal, 4 (2), 199-210.

[21] Rahardja, U., Aini, Q., \& Santoso, NPL (2018). YII Integration Framework Based on API in Attendance Assessment System. SISFOTENIKA, 8 (2), 140-152.

[22] Rahardja, U., Lutfiani, N., Lestari, AD, \& Manurung, EBP (2019). Raharja Era University Innovation in Disruptive Using iLearning Methodology. Asian Scientific Information Technology Journal, 13 (1), 23-34.

[23] Suprastyo, D., Siregar, H., \& Mulatsih, S. (2020). Analysis of Agricultural Land Ownership Distribution and Farming Income in Karawang Regency. TATALOKA, 22 (1) ...

[24] Zheng, W., Zheng, Z., Chen, X., Dai, K., Li, P., \& Chen, R. (2019). NutBaaS: Blockchain Platform as a Service. Access IEEE, 7, 134422-134433.

[25] Lu, H., Huang, K., Azimi, M., \& Guo, L. (2019). Blockchain technology in the oil and gas industry: Overview of applications, opportunities, challenges and risks. Access IEEE, 7, 41426-41444.

[26] Xie, J., Tang, H., Huang, T., Yu, FR, Xie, R., Liu, J., \& Liu, Y. (2019). A Blockchain Technology Survey Applied to Smart Cities: Research Problems and Challenges. IEEE Communication Survey \& Tutorial. 
[27] Shahzad, B., \& Crowcroft, J. (2019). Reliable Electronic Voting Using Customized Blockchain Technology. Access IEEE, 7, 24477-24488.

[28] Nasution, LH (2018). EVALUATION OF E-JOURNAL UTILIZATION IN THE PANCA BUDI MEDAN DEVELOPMENT UNIVERSITY. Net Journal. Library and Information, 1 (1), 40-46.

[29] Handayani, I., Aini, Q., \& Sari, N. (2018). Utilization of OJS-Based iJC System as E-Journal Media in YUPPENTEK STISIP. Technomedia Journal, 2 (2), 94-106.

[30] Laila, N., \& Anita Sindar, RMS (2019). Implementation of LSB Steganography with Vigenere Cipher Encryption in the Image. Scientifico: Computer Science Informatics Journal, 1 (2), 47-5 ...

[31] Octavianingrum, M., Siambaton, DA, \& Dewi, AFK (2018). MODIFICATION OF VIGENERE CIPHER WITH SHOCKING KEY BLOCK ENCRYPTION METHOD. Sendika Proceedings, 4 (1).

[32] NATALIANA, D., ANWARI, S., \& AKBAR, MS (2017). Implementing a Home Security System Prototype by Using Mega Arduino-based Access Codes. ELKOMIKA: Journal of Electrical Energy Engineering, Telecommunications Engineering \& Electronic Engineering, 5 (2), 119.

[33] Rais, NSR, Supriati, R., \& Danti, SI (2018). Open Journal System (OJS) Version 3 Installation as a Support for Scientific Journal Management and Publication Activities. Technomedia Journal, 2 (2), 66-80.

[34] Wijaya, NH (2017). Development of E-journal Research Results from Respati Yogyakarta Faculty of Health Sciences Students. Respati, 9 (26).

[35] Ningrum, PT, Suria, O., \& Witanti, A. (2018). Library E-Resource Design Using MobileBased Customer Relationship Management. Journal of Exploratory Informatics, 8 (1), 59-68. 